\title{
ROLA INFRASTRUKTURY TRANSPORTU JAKO JEDNEGO Z CZYNNIKÓW ROZWOJU REGIONALNEGO
}

\author{
The role of transport infrastructure as one of the regional development indicators
}

\author{
Jakub Majewski \\ Centrum Europejskich Studiów Regionalnych i Lokalnych (EUROREG), Uniwersytet Warszawski, Krakowskie Przedmieście 30, 00-927 Warszawa \\ e-mail: jakubmajewski@uw.edu.pl
}

https://orcid.org/0000-0001-5754-9772

\section{Cytacja:}

Majewski J., 2021, Rola infrastruktury transportu jako jednego z czynników rozwoju regionalnego, Prace Komisji Geografii Komunikacji PTG, 24(3), 7-18.

Streszczenie: Celem niniejszego artykułu jest prezentacja miejsca infrastruktury transportowej w programowaniu rozwoju społeczno-gospodarczego oraz analiza charakteru i roli tego czynnika w wybranych teoriach rozwoju regionalnego. Pierwsza część pracy opisuje metodę badań oraz wykorzystywane źródła. Część druga zawiera syntetyczny przegląd literatury z zakresu ekonomiki transportu i wskazuje na elementy kluczowe z punktu widzenia rozwoju społeczno-gospodarczego oraz, co za tym idzie, zainteresowania władz publicznych. W części trzeciej opisana jest dyskusja tocząca się wokół oczekiwanej roli inwestycji infrastrukturalnych oraz ich miejsca w wybranych koncepcjach rozwoju regionalnego. Koncentruje się ona wokół dylematu "wyprzedzającego", bądź „wtórnego" modelu rozbudowy infrastruktury, a także roli tego zagadnienia na tle innych czynników rozwoju regionalnego. Całość zamyka podsumowanie, które zawiera wnioski na temat roli sfery transportu we wspieraniu rozwoju regionów oraz konkluzję, zgodnie z którą infrastruktura transportu stanowi element niezbędny do kreowania dostępności i równolegle wewnętrznego potencjału regionów.

Słowa kluczowe: infrastruktura, polityka transportowa, czynniki rozwoju regionalnego

Abstract: The aim of this paper is to present the place of transport infrastructure in socio-economic development programming and to analyse the nature and role of this factor in selected theories of regional development. The first part of the paper describes the research method and sources used. The second part contains a synthetic review of the literature on transport economics and indicates the key elements from the point of view of socio-economic development and, consequently, the interest of public authorities. The third part describes the discussion on the expected role of infrastructure investments and their place in selected concepts of regional development. It focuses on the dilemma of the "anticipatory" or "secondary" model of infrastructure development and the role of this issue against the background of other regional development factors. The book closes with a conclusion on the role of the transport sphere in supporting regional development and the conclusion that transport infrastructure is an indispensable element in creating accessibility and, in parallel, the internal potential of regions.

Keywords: infrastructure, transport policy, regional development 


\section{Wstęp}

Mimo dynamicznych zmian modelu funkcjonowania społeczeństw i gospodarek, szybkiego wzrostu roli zdalnej pracy i nauki czy poszerzania zakresu usług świadczonych drogą cyfrową odpowiednia dostępność transportowa pozostaje cechą uznawaną za pożądaną i podnoszącą w wielu wymiarach wartość określonej lokalizacji (van Wee, 2016). Obok uwarunkowań fizycznogeograficznych i geopolitycznych elementem niezbędnym do jej zapewnienia jest odpowiednia infrastruktura transportowa, która gwarantuje sprawny przepływ ludzi i towarów - w części przypadków bezpośrednio, a w wybranych gałęziach transportu - jako kluczowy element budowania oferty przewozowej.

Celem niniejszego artykułu jest prezentacja miejsca infrastruktury transportowej w programowaniu rozwoju społeczno-gospodarczego oraz analiza charakteru i roli tego czynnika we współczesnych teoriach rozwoju regionalnego. W związku z tym autor stawia pytanie badawcze o to, jak postrzegane są kluczowe zadania dla sfery infrastrukturalnej w budowaniu przewag konkurencyjnych regionów.

Ze względu na interdyscyplinarny charakter opisywanej analizy zagadnienie to przedstawione jest zarówno z perspektywy ekonomiki transportu, jak i teorii rozwoju. Wynika to z faktu, że transport, który sam ma charakter przede wszystkim techniczny i usługowy wobec innych dziedzin, pełni zarazem rolę medium gospodarczego, kulturowego i społecznego, a jego niedomagania przekładają się na dysfunkcjonalność poszczególnych obszarów aktywności i systemów terytorialnych. W rezultacie słabo rozwinięta infrastruktura transportowa uznawana jest za element wyraźnie utrudniający dostępność danego terytorium dla mieszkańców i firm (Wojtowicz, Olechnicka, 2016).

Przesłanką, która od strony naukowej przesądziła o zainteresowaniu zaproponowaną tematyką badawczą, była obserwacja wskazująca na stopniowy spadek zainteresowania analizami o charakterze teoretycznoprzeglądowym w obszarze geografii transportu i koncentracja aktualnych nurtów badawczych na opisie praktycznego wymiaru i skutków postępującego rozwoju infrastruktury. Stąd elementem artykułu jest opis rozważań o zależnościach pomiędzy rozwojem infrastruktury i jej otoczenia społeczno-gospodarczego na gruncie współczesnych dyskusji o koncepcjach rozwoju regionalnego.

Z drugiej strony przygotowanie i opublikowanie tekstu zbiega się w czasie z okresem opracowywania nowych programów infrastrukturalnych, które mają na celu zainicjowanie lub wzmocnienie procesów rozwojowych na poziomie regionalnym. Strategie te formułują daleko idące oczekiwania dotyczące efektów planowanych inwestycji, nie zawsze biorąc pod uwagę szereg innych uwarunkowań decydujących o ostatecznym efekcie. W wymiarze praktycznym tekst może być więc użyteczny zarówno dla osób prowadzących badania nad transportem i poszukujących odniesień do dorobku teoretycznego w tej dziedzinie, jak i dla autorów dokumentów programujących procesy rozwoju regionalnego.

\section{Metoda badań}

Zaproponowany cel i przedmiot pracy wskazują, że podstawową metodą badań powinna być analiza literatury, zarówno z obszaru transportu, jak i rozwoju regionalnego oraz próba znalezienia elementów wspólnych łączących badania w obu dziedzinach. W literaturze transportowej powyższe zależności opisane są bowiem stosunkowo skromnie i koncentrują się przede wszystkim na właściwościach fizycznych, technicznych oraz technologii przewozów. Związki z otoczeniem społeczno-gospodarczym ograniczają się natomiast głównie do organizacji procesu przewozowego, ewentualnie do optymalizacji działalności w celu odpowiedniego zaspokajania potrzeb zgłaszanych przez rynek. Z kolei w piśmiennictwie z zakresu rozwoju regionalnego, mimo stosunkowo bogatych odniesień do sfery transportu, relatywnie rzadko analizowane są przyczyny szczególnego charakteru zapotrzebowania na transport. W rezultacie dopiero zestawienie obu perspektyw i przegląd wspólnego dorobku oraz teorii pozwala na prześledzenie ewolucji i formułowanie szerszych wniosków na temat współczesnej roli czynnika transportowego w procesach rozwojowych.

O wyborze konkretnych pozycji, z szerokiego zbioru literatury opisującej zarówno teorie rozwoju regionalnego, jak i uwarunkowania przestrzenne i infrastrukturalne, zdecydowała przygotowana we wstępnej fazie prac kwerenda biblioteczna. Pozwoliła ona na skompletowanie pozycji źródłowych i prac najlepiej charakteryzujących kolejne etapy opisywanej ewolucji. Dodatkowo, zwłaszcza w przypadku nowszych materiałów, przegląd został wsparty analizą baz danych wykorzystującą frazy i słowa kluczowe.

\section{Przegląd literatury}

\subsection{Generalna rola działalności transportowej w rozwoju społecznym i gospodarczym}

Potrzeby transportowe mają charter podstawowy i są konsekwencją realizacji zarówno potrzeb natury biologicznej, socjologicznej czy kulturowej, jak i złożonych celów, zadań i zamierzeń wymagających funkcjonowanie wyspecjalizowanej gałęzi gospodarki i niezbędnej infrastruktury. Rozmiary, charakter i częstotliwość 
potrzeb transportowych kształtują czynniki wynikające z rozwoju stosunków gospodarczych, społecznych i politycznych, a współcześnie również z poziomu cyfryzacji. Jednak, bez względu na poziom rozwoju, każda potrzeba przemieszczenia osób i ładunków ma określone znaczenie gospodarcze i społeczne.

Praktycznie od początku istnienia cywilizacji i organizacji pierwszych społeczeństw transport przekształcił się w potrzebę celowego i zorganizowanego przemieszczania, wykorzystując do tego celu coraz bardziej zaawansowane środki i urządzenia. Wraz z rozwojem gospodarki rozwijała się ściśle z nią powiązana działalność transportowa, warunkująca jednocześnie rozwój poszczególnych społeczności i obszarów. Wraz z rozwojem sieci osadniczej oraz powiązań społecznych i gospodarczych w poszczególnych układach terytorialnych postępował rozwój sieci transportowej, wykorzystującej coraz bardziej zaawansowany technicznie i skomplikowany system infrastrukturalny.

Na wielu obszarach zmiany technologii transportowych kreowały zmiany stylu i modelu funkcjonowania całych gospodarek i społeczeństw. Wyrazem tego było przyspieszanie tempa życia i wzrost aktywności, które przekładały się na dalszy wzrost potrzeb transportowych. Dodatkowo dobrem coraz cenniejszym stawał się czas. Dlatego przed transportem stawiano coraz to nowe wymagania, oczekując przyspieszenia przemieszczania oraz możliwości efektywnego korzystania z czasu spędzanego w podróży (Wielowiejski, 1984).
Odzwierciedleniem wzrostu gospodarczego i dobrobytu społecznego stały się współczesne potrzeby transportowe wynikające m.in. z:

- rosnącej mobilności obywateli,

- rozwoju gospodarki światowej i międzynarodowego podziału pracy,

- procesów globalizacyjnych i integracji regionów,

- rozwoju powiązań telekomunikacyjnych i przepływu informacji,

- nowych form zagospodarowania czasu wolnego. W miarę rozwoju i coraz bardziej złożonej struktury działalności transportowej rosło zainteresowanie odpowiednim planowaniem i przygotowywaniem infrastruktury umożliwiającej podróże i transport towarów. Zauważono bowiem, że na poziomie regionalnym korzyści płynące $z$ dobrze rozwiniętej infrastruktury mają zarówno wymiar wewnętrzny, obejmujący wsparcie spójności i integralności, gwarantujące mobilność mieszkańców, wzrost jakości życia, jak i wymiar zewnętrzny - niezbędny do poszerzania spektrum kontaktów gospodarczych i społecznych, otwierania i udostępnienia rynków zbytu, tranzytu, przepływu siły roboczej, rozwoju turystyki (Krzemiński, 2005). Jednocześnie zależność ta stała się dwukierunkowa, bo dobra dostępność regionu sprzyjała intensyfikacji relacji gospodarczych, w tym przyciąganiu zewnętrznych czynników produkcji oraz ułatwiała dostęp do pozaregionalnych rynków zbytu (przykłady zależności w obu wymienionych sferach ilustruje tab. 1).

Tab. 1. Wybrane efekty rozwoju infrastruktury transportowe.

\begin{tabular}{|c|c|c|}
\hline Efekty ekonomiczne & Efekty społeczno-gospodarcze & Efekty środowiskowe \\
\hline $\begin{array}{l}\text { Przepływy finansowe: } \\
\text { - koszty budowy, utrzymania } \\
\text { eksploatacji i remontów; } \\
\text { - przychody z opłat za dostęp. } \\
\text { Bezpośrednie korzyści dla } \\
\text { użytkowników: } \\
\text { - skrócenie czasu podróży } \\
\text { i przewozu; } \\
\text { - zmniejszenie kosztów } \\
\text { eksploatacji środków transportu; } \\
\text { - poprawa bezpieczeństwa ruchu. } \\
\text { Bezpośrednie efekty sieciowe: } \\
\text { - transport wzbudzony: nowe } \\
\text { przewozy, zmiany celu } \\
\text { i czasu wyjazdu oraz miejsca } \\
\text { przeznaczenia; } \\
\text { - przesunięcia międzygałęziowe; } \\
\text { - zmiany jakości usług (wzrost } \\
\text { komfortu i wygody). }\end{array}$ & $\begin{array}{l}\text { Zmiany dostępności transportowej. } \\
\text { Zmiany produktywności. } \\
\text { Zmiany dochodów i zatrudnienia. } \\
\text { Redystrybucja zatrudnienia i dochodu } \\
\text { między regionami i grupami } \\
\text { społecznoekonomicznymi. } \\
\text { Migracja czynników produkcji (m.in. } \\
\text { zmiany mobilności oraz delokalizacja } \\
\text { przedsiębiorstw). } \\
\text { Zmiany wartości nieruchomości. }\end{array}$ & $\begin{array}{l}\text { Wpływ na środowisko naturalne: } \\
\text { - zmiany klimatyczne; } \\
\text { - zużycie zasobów naturalnych; } \\
\text { - zmniejszenie bioróżnorodności; } \\
\text { - zanieczyszczenie powietrza, } \\
\text { gleby, wód powierzchniowych } \\
\text { i gruntowych; } \\
\text { - hałas i wibracje. } \\
\text { Wpływ na dziedzictwo narodowe, } \\
\text { miejsca szczególnie atrakcyjne } \\
\text { o znaczeniu historycznym lub } \\
\text { archeologicznym. }\end{array}$ \\
\hline
\end{tabular}

Źródło: Opracowanie własne na podstawie: Rosik, Szuster (2008), s. 23; Kamińska, Rusak (2000), s. 16; Łatuszyńska (2004), s. 29; Rydzkowski, Wojewódzka-Król (1997), s. 25; Impact of Transport Infrastructure Investment on Regional Development, OECD (2002), s. 21. 


\subsection{Szczególne cechy infrastruktury transportu determinujące jej związki z programowa- niem rozwoju}

Uwarunkowania historyczne są tylko jednym ze źródeł specyfiki działalności transportowej powodującym, że znaczna część tego obszaru nie podlega samoregulacji rynkowej i ciąży ku interwencji władzy publicznej (Knieper, 1966). Na specyficzne wymagania sfery transportu, a tym samym infrastruktury jako formy zagospodarowania przestrzeni, składają się jej cechy fizyczne, takie jak (Paprocki, Pieriegud, 2005; Ślawska, 2019):

- wysoka kapitałochłonność i majątkochłonność, determinująca duże nakłady finansowe i zwrot z inwestycji w bardzo długim okresie,

- niepodzielność ekonomiczna i niezbędna kompletność, oznaczająca bardzo ograniczone efekty wynikające $z$ budowy etapami,

- wysoki udział kosztów stałych i progowa efektywność, wynikająca z napełniania, a następnie przekraczania przepustowości i konieczności dalszej rozbudowy,

- długowieczność i wysokie koszty utrzymania,

- komplementarność i transpozycja korzyści na inne działy gospodarki orazżycie społeczne, wynikająca z faktu, że przewozy przynoszą korzyści przedsiębiorstwom i pasażerom, a nie bezpośrednio właścicielowi czy operatorowi infrastruktury.

Spośród wyżej wymienionych elementów najważniejsza z punktu widzenia kreowania rozwoju jest wysoka kapitałochłonność inwestycji infrastrukturalnych. Potrzeby w tym zakresie - zwłaszcza przy inwestycjach o wysokich parametrach - wynikają głównie z niepodzielności technicznej i ekonomicznej inwestycji'. Powoduje ona, że skala dużych inwestycji transportowych w znacznej mierze przekracza możliwości większości budżetów lokalnych. W rezultacie przygotowywane i realizowane są one przede wszystkim na poziomie centralnym i regionalnym, niejednorodnie przy istotnym udziale organizacji międzynarodowych.

Dodatkowo problem kapitałochłonności potęguje niemożliwość etapowania inwestycji, szczególnie w początkowych stadiach rozwoju. Dopiero w kolejnych fazach wykazuje ona tendencję malejącą, tak aby w rozwiniętych regionach, charakteryzujących się wysokim stopniem wykorzystania infrastruktury,

Kapitałochłonność jest dodatkowo zróżnicowana, w zależności od analizowanej gałęzi transportu i parametrów jakościowych. Najbardziej kapitałochłonna jest budowa dróg kołowych - w szczególności autostrad - oraz kolei, niższą kapitałochłonnością charakteryzuje się natomiast infrastruktura transportu wodnego śródlądowego. ustabilizować się na stałym, ale nadal bardzo wysokim poziomie (Frey, 1970). W związku z tym zjawisko korzyści skali jest charakterystyczne dla obiektów infrastrukturalnych $w$ transporcie dopiero $w$ długim okresie, gdy przekłada się na długookresowe koszty eksploatacji².

Wynikająca z niepodzielności technicznej niepodzielność ekonomiczna oznacza małą użyteczność oraz nieopłacalność cząstkowej realizacji inwestycji infrastrukturalnych. Tylko przy całościowym i kompleksowym wyposażeniu oraz "minimalnym" rozmiarze realizacja projektów infrastrukturalnych $w$ transporcie ma uzasadnienie, choć nawet $w$ takich sytuacjach nie jest zagwarantowana bezpośrednia zależność pomiędzy nakładami a efektami, zwłaszcza w krótkim okresie. Powyższe cechy (Rosik, Szuster, 2008) wymuszają konieczność:

- perspektywicznego planowania (długi okres realizacji, ograniczona podatność na angażowanie się kapitału prywatnego),

- mobilizowania znacznych środków (niepodzielność techniczna i ekonomiczna),

- długiego okresu zamrożenia kapitału i niskiej efektywności (długi okres eksploatacji, duży udział kosztów stałych).

Opisana w literaturze charakterystyka działalności transportowej oraz przekonanie o istotnej roli tego sektora jako instrumentu niwelowania barier o charakterze ekonomicznym doprowadziły do rozpowszechnienia poglądu, że dostęp do tej dziedziny powinien mieć charakter powszechny. Implikuje to konieczność zapewnienia możliwie szerokiej swobody poruszania się i równego traktowania użytkowników. W związku z powyższym jako uniwersalny przyjmowany jest model, w którym infrastruktura transportowa i część usług przewozowych ma charakter publiczny, a korzystanie z nich odbywa się na podstawie regułjednolitych dla wszystkich użytkowników (Liberadzki, Mindur, 2007).

Aby to wyjaśnić, należy odwołać się do czynników niesprawności rynku, powodujących nieefektywną alokację zasobów. Należą do nich następujące kategorie (Hausner, 2008):

1) public goods - dobra publiczne, których dostarczaniem nie są zainteresowani prywatni wytwórcy,

2) externalities - efekty zewnętrzne, wynikające z działań podmiotów szkodzących, bądź nagradzających inne podmioty, bez rekompensaty bądź opłaty,

3) incomplete markets and imperfecta or asymmetric information - rynki niepełne i niedoskonałe z asymetryczną informacją, wpływające na wzrost kosztów,

Przyczyną występowania zjawiska korzyści skali jest niepodzielność techniczna. 
4) naturalne monopole, które wykluczają konkurencję,

5) nierówne rozkłady dochodów i bogactwa ${ }^{3}$.

Konsekwencją powyższych cech transportu, a zwłaszcza infrastruktury, jest generalna zasada obowiązująca we współczesnych państwach, gdzie w większym bądź mniejszym stopniu za zarządzanie tą działalnością odpowiadają organy publiczne szczebla krajowego i regionalnego ${ }^{4}$. Powoduje to, że działalność na tym polu wykracza poza wymiar stricte ekonomiczny, służąc wspomnianym na wstępie celom społecznym, gospodarczym i militarnym, a także zwiększaniu spójności oraz polityce międzynarodowej.

Publiczny charakter i konieczność rozbudowanego planowania, a jednocześnie znaczne zróżnicowanie dostępności usług transportowych zbliża działalność do obszaru programowania rozwoju społecznego i regionalnego. Analizując transport pod względem funkcjonalnym należy zauważyć, że szeroko rozumianą rolą władz publicznych - zarówno na poziomie centralnym, jak i regionalnym - jest nie tylko budowa i utrzymanie infrastruktury, ale również zapewnienie pewnego podstawowego poziomu obsługi transportowej.

Ostatnim, bardzo szybko zyskującym na znaczeniu obszarem związanym z szerokim oddziaływaniem sfery transportowej, jest niwelowanie negatywnego oddziaływania tej sfery na otoczenie - w tym przede wszystkim na zdrowie, środowisko i klimat. Polityka w tym zakresie odwołuje się do koncepcji rozwoju zrównoważonego, czyli kształtowania poszczególnych sektorów gospodarki w sposób uwzględniający aspekty znacznie szersze niż tylko stosunek do relacji między państwem a wolnym rynkiem ${ }^{6}$. Trend szeroko

3 Spośród powyższych kategorii, co najmniej pozycje 1, 2 i 4 można bezpośrednio odnieść do sfery infrastrukturalnej.

$4 \quad$ W przypadku części infrastrukturalnej nawet powoływane w tym celu przedsiębiorstwa zwalniane są z obowiązku generowania zysków i traktuje się je jak organizacje non-profit, odpowiedzialne za możliwie szeroki tani dostęp.

5 Tym samym, do ekonomicznych uwarunkowań sektora transportu, obserwowanych zwłaszcza na poziomie operacyjnym dochodzi kolejna, wskazująca, że niebilansowanie kosztów przychodami nie musi oznaczać utraty korzyści. Przyjmuje się bowiem, że deficyt, nawet w sytuacji, gdy generuje bezpośrednią stratę w przedsiębiorstwie przewozowym, rekompensować mogą korzyści gospodarcze i społeczne, przewyższające poziom strat finansowych (Liberadzki, Mindur, 2007). W związku z tym w przewozach pasażerskich, oprócz racjonalności gospodarczej opartej na regułach rynkowych, występuje znaczący obszar, który określa się jako public service obligation, czyli obowiązek świadczenia usługi publicznej. Na tej podstawie angażuje się środki publiczne w transport.

6 Idea zrównoważonego rozwoju po raz pierwszy oficjalnie sformułowana została w 1987 r. w raporcie Komisji ONZ opisywany w literaturze (Domański, 1992; Rietveld, Stough, 2004; Banister, 2007; Wittneben i in., 2009) materializuje się w dokumentach przesądzających o kierunkach rozwoju transportu - w tym również w najnowszej, opublikowanej w 2020 r. przez Komisję Europejską "Strategii Zrównoważonej i Inteligentnej Mobilności". Dokument ten transponuje na sektor priorytety Europejskiego Zielonego Ładu, wskazuje na nieskuteczność dotychczasowych prób ograniczania emisji z sektora transportu i podkreśla konieczność rozdzielenia dalszego wzrostu gospodarczego i transportochłonności. Wskazuje jednocześnie, że zadań w tym zakresie nie można pozostawić wyłącznie mechanizmom rynkowym, a impulsem do głębokiej restrukturyzacji sektora muszą być zarówno nowe, restrykcyjne regulacje prawne, jak i zwiększone inwestycje publiczne. Interwencja publiczna przygotowana na poziomie unijnym, realizowana przede wszystkim na szczeblu krajowym i regionalnym, ma zmienić europejski transport w system zrównoważony i konkurencyjny, a równocześnie odporny na przyszłe wstrząsy?.

\section{Dyskusja}

\subsection{Dylemat odnoszący się do wyprzedzającej bądź wtórnej konieczności rozwoju infrastruktury}

ds. Środowiska i Rozwoju, zatytułowanym Nasza wspólna przyszłość. Wskazywał on ogólne zasady przyszłego rozwoju gospodarczego i cywilizacyjnego, zgodnego z potrzebami ochrony środowiska. Idea ta, która początkowo była próbą uzupełnienia istniejących koncepcji rozwoju o wymiar ekologiczny i nadania im cech, takich jak trwałość, oszczędność zasobów czy wielopokoleniowość ostatecznie jednak zyskała niezależność, a za podstawę przyjęła dążenie do zachowania równowagi między celami społecznymi, ekonomicznymi a środowiskowymi (Domański, 1992).

7 Kwestia zarówno pojęcia, jak i praktycznej realizacji zasad zrównoważonego rozwoju transportu znacznie przekracza ramy niniejszego artykułu i zasługuje na osobne, zdecydowanie szersze omówienie. W tym miejscu można jedynie zasygnalizować, że założenia najnowszej strategii zakładają szeroką transformację sektora, która obejmować będzie upowszechnienie bezemisyjnych pojazdów, statków i samolotów, upowszechnienie odnawialnych źródeł energii i paliw niskoemisyjnych, zrównoważenie struktury transportu międzymiastowego i miejskiego, wspieranie ekologicznego transportu towarowego, wprowadzenie nowego systemu opłat za dostęp do infrastruktury transportowej i powiązanie go z emisją gazów cieplarnianych. Wymienione elementy będą miały skutki wykraczające poza branżę i w związku z tym należy się spodziewać, że nawet w przypadku niepełnej lub opóźnionej realizacji będą miały bardzo istotny wpływ na generalne procesy rozwojowe, w tym również na rozwój na poziomie regionalnym. 
Opisane w literaturze z zakresu ekonomiki transportu szczególne cechy infrastruktury i ich związki z zarządzaniem sferą publiczną kontrastują w pewnym stopniu z faktem, że w systemach demokratycznych i warunkach gospodarki wolnorynkowej jest to nadal jedna z gałęzi swobodnej aktywności społecznej i konkurencyjnej gospodarki. I w tym miejscu pojawia się kluczowy dylemat dotyczący dopuszczalnego charakteru ewentualnych interwencji ze strony władz publicznych. Materializuje się on w formie listy pytań odnoszących się do zakresu i instrumentów ewentualnej interwencji w tym obszarze. Jako przykłady można tu wymienić następujące kwestie (Majewski, 2016):

- W jakim stopniu odpowiadać na potrzeby społeczne, a w jakim je kształtować?

- Czy i jak dalece ingerować w wolność wyboru, kształtując podział zadań między środkami transportu?

- Czy interes gospodarczy przedkładać nad społeczny, czy odwrotnie - np. preferując przewozy pasażerskie lub towarowe?

- Jaką wagę nadać częściowo sprzecznym celom: sprawności systemu, bezpieczeństwu ruchu i ochronie środowiska?

- W jakim stopniu brać pod uwagę interesy i powiązania międzynarodowe, a w jakim krajowe i regionalne? W konsekwencji, jaki rodzaj ruchu preferować?

- Jakie przyjmować proporcje pomiędzy własnością prywatną a państwową?

- Jak dzielić środki między inwestycje, modernizacje i utrzymanie? lle przeznaczać na istniejącą, a ile na nową infrastrukturę i kiedy zastępować starsze rozwiązania?

- Czy wyrównywać dysproporcje, czy maksymalizować efekty - np. w skali regionu czy kraju?

Z punktu widzenia programowania rozwoju regionalnego szczególnie ciekawa jest ostatnia pozycja. Jest ona o tyle szczególna, że zarówno krajowe badania empiryczne (Ratajczak, 2000; Wojewódzka, 2000, Komornicki, 2010, Rosik, 2004; Bąk, 2014; Burnewicz, 2014; Brdulak i in., 2014; Hoszman, 2014; Koźlak, 2014; Pawłowska, 2014; Ważna, 2014; Hryniewicz, 2017; Matczak i in., 2020), jak i podobne prace prowadzone w tym zakresie za granicą (Lakshmanan, 2011; Rodriguez-Pose, Fratesi, 2004; Barca i in., 2012; Meersman, Nazemzadeh, 2017; Cigu i in., 2019) nie pozwalają w sposób jednoznaczny przesądzić, który z wymienionych kierunków interwencji przynosi lepsze efekty.

Zwolennicy doktryny neoliberalnej rozstrzygną bowiem opisany dylemat na korzyść efektywności ekonomicznej. Z tej perspektywy zadaniem władz jest bowiem tworzenie odpowiednich regulacji prawnych dla wolnych mechanizmów rynkowych, które najskuteczniej prowadzić mają do generowania impulsów rozwojowych i samoistnego wyrównywania poziomu rozwoju społeczno-gospodarczego w rożnych skalach przestrzennych (Gałązka, 2017). Zasada, zgodnie z którą związki polityki i gospodarki powinny być jak najmniejsze, po przełożeniu na grunt inwestycji infrastrukturalnych oznacza, że inwestować należy przede wszystkim tam, gdzie istniejące systemy transportowe są niewydolne. Tym samym przesłanką do zaangażowania sił i środków publicznych będą zjawiska, takie jak wyczerpywanie się pojemności lub przepustowości, niedostateczne lub nieadekwatne do zamówień możliwości przewozowe, długotrwała kongestia bądź narastanie problemów z bezpieczeństwem ruchu.

Przeciwieństwem doktryny liberalnej będzie podejście przyznające priorytet interwencjonizmowi, rozumianemu jako „aktywne, zmierzające do realizacji określonych celów, oddziaływanie państwa na procesy gospodarcze i społeczne" (Markowski, 1992). Zgodnie z jego założeniami w wielu sferach - w tym również w transporcie - „rynek sam nie jest w stanie stworzyć mechanizmów stymulujących harmonijny wzrost i najkorzystniejsze ustrukturalizowanie gospodarki" (Nieciuński, 1991).

Interwencjonizm opierający się na twierdzeniu, że w praktyce nie jest możliwe odizolowanie działalności państwa od presji interesów gospodarczych ani wyeliminowanie ingerencji politycznej w działalność gospodarczą wskażą na konieczność korygowania mechanizmów rynkowych i wykorzystania przez instytucje publiczne instrumentów uzupełniających działanie mechanizmów rynkowych (Jaskólski, 1999).

Praktycznym przejawem tego nurtu będzie koncepcja stymulowania rozwoju, oparta na wyprzedzającej budowie i rozbudowie infrastruktury. Kluczowe jej założenia to pochodna długiego okresu przygotowywania inwestycji transportowych. Zwolennicy tej teorii podkreślają konieczność wyprzedzania przez inwestycje transportowe rozwoju osadnictwa czy produkcji. Bezpośrednim środkiem realizacji tak określonych celów są duże przedsięwzięcia inwestycyjne w sferze infrastrukturalnej. Zwolennicy stymulowania rozwoju społeczno-gospodarczego z wykorzystaniem inwestycji infrastrukturalnych przytaczają argumenty przekonujące, że skutki budowy lub modernizacji szlaków transportowych odczuwają nie tylko bezpośredni ich użytkownicy, ale całe społeczności i rejony gospodarcze.

Przykładem powyższego podejścia jest koncepcja tzw. wielkiego pchnięcia infrastrukturalnego, sformułowana w latach 50. XX w. przez amerykańskich ekonomistów, takich jak urodzony w Polsce Paul Rosenstein-Rodan czy Ragnar Nurkse. Wskazują oni, że ze względu na niepodzielność infrastruktury niemożliwa jest szybka budowa lub modernizacja w odpowiedzi na zmiany popytu. Tymczasem brak urządzeń in- 
frastrukturalnych, szczególnie w pierwszych fazach rozwoju krajów czy regionów powoduje powstanie tzw. „błędnego koła niedorozwoju” (Pastuszka, 2014).

Zjawiskiem wtórnym, związanym ze spójnością społeczną, a będącym konsekwencją niedorozwoju transportu, jest pogarszanie poziomu życia, zwłaszcza $w$ regionach zlokalizowanych peryferyjnie i na obszarach słabo skomunikowanych z centrami życia społeczno-gospodarczego. To "wypłukiwanie" obszarów upośledzonych infrastrukturalnie potęguje ich marginalizację, ograniczając dodatkowo możliwość wyrównywania różnic i ograniczając potencjał adaptacyjny ${ }^{8}$.

Niedostosowanie infrastruktury do potrzeb w wymiarze regionalnym może wywołać negatywne skutki zarówno w samym sektorze transportu, jak i w pozostałych dziedzinach gospodarki. Jako bezpośrednie skutki dla sektora są to m.in. (Burnewicz, Wojewódzka-Król, 1993):

- wzrost czasu i kosztów przewozu,

- wzrost czasu i kosztów składowania,

- obniżanie jakości i niezawodności usług,

- niekorzystne zmiany strukturalne, w tym dysproporcje pomiędzy różnymi gałęziami transportu,

- nieprawidłowy rozwój infrastruktury,

- wzrost nakładów spowodowany presją inwestycji o charakterze interwencyjnym i niwelującym.

Słabo rozwinięta infrastruktura transportowa, obok ograniczonego dostępu infrastruktury informatycznej i telekomunikacyjnej, uznawane są za element wyraźnie utrudniający dostępność danego terytorium dla mieszkańców i firm (Wojtowicz, Olechnicka, 2016).

\subsection{Ewolucja roli czynników transportowych $w$ teoriach rozwoju regionalnego}

Jeśli, opierając się na opisanych poprzednich częściach uwarunkowaniach i oczekiwaniach, wynikających ze specyfiki działalności transportowej, infrastrukturę i działalność transportową uznamy za jeden z przedmiotów naturalnego zainteresowania władz publicznych, to siłą rzeczy staje się ona obszarem programowania rozwoju również na poziome regionalnym ${ }^{9}$. Tym samym dziedzina ta staje się także

8 W literaturze pojawiają się też poglądy, że rozwój infrastruktury, zwłaszcza umożliwiającej sprawne dojazdy do oddalonych miejsc pracy może wręcz przyspieszać ten proces, wzmacniając uzależnienie regionów peryferyjnych od centrum.

9 Polityka transportowa może być prowadzona również na poziomie lokalnym, choć ze względu na wspomniane cechy takie jak kapitałochłonność czy niepodzielność techniczna ma ona tu mniejszy zasięg i często pełni rolę uzupełniającą. W większości przypadków jej domeną jest realizacja podstawowych, codziennych potrzeb trans- jednym z czynników wpływających na różnicowanie się procesów społecznych i gospodarczych w przestrzeni, które wykorzystywane są zarówno w opracowywaniu teorii rozwoju regionalnego, jak również w praktyce konstruowania instrumentów polityki regionalnej (Smętkowski, 2013).

Bardzo dużą wagę do kwestii powiązań przestrzennych przykładały już klasyczne teorie lokalizacji m.in. A. Webera, W. Christallera oraz A. Löscha. Przyjmowały wprawdzie daleko idące uproszczenia - zakładające m.in., że przestrzeń ma charakter homogeniczny i koszty transportu są równe - ale samą działalność przewozową stawiały w kluczowym miejscu. Postęp badań nad zróżnicowaniem przestrzennym na wielu etapach uwzględniał czynnik transportowy jako istotny element wyjaśniający procesy akumulacji kapitału w określonych regionach i charakteryzujący się przewagą konkurencyjną, opartą na zasobach ziemi i pracy (wybrane przykłady w tym zakresie ujęto w tab. 2).

Wraz z rewolucją przemysłową odległość fizyczna i związane z nią proste koszty transakcyjne zaczęły tracić na znaczeniu, ustępując budowaniu relacji niematerialnych i efektom aglomeracji Przyspieszanie obiegu gospodarczego spowodowało, że, zamiast dostępności fizycznej o sukcesie rozwojowym zaczęła decydować dostępność kosztowa, a w kolejnym etapie - czasowa. Tym samym klasycznie interpretowaną odległość geograficzną zaczęły silnie modyfikować technologie i inwestycje transportowe oraz telekomunikacyjne. W wymiarze przestrzennym ważniejsze niż materialna wymiana towarów stało się skupienie przepływów o charakterze niematerialnym (Gorzelak, Smętkowski, 2005).

Rozwijające się wraz z rewolucją cyfrową koncepcje rozwoju regionalnego, odnoszące się do przewag konkurencyjnych związanych z innowacyjnością, przeniosły akcenty z tradycyjnych czynników produkcji na informację. Przy okazji utraty znaczenia przez czynniki takie jak ziemia, praca i kapitał siłą rzeczy obniżyła się również ranga transportu i infrastruktury (Smętkowski, 2013).

W rezultacie przyjęto, że w gospodarce informacyjnej miasta i regiony konkurują o kapitał i innowacyjne branże działalności gospodarczej. Starają się przygotować atrakcyjne otoczenie dla wielkich korporacji transnarodowych i wysokiej klasy specjalistów. Władze, na równi z poprawą dostępności i standardów infrastruktury, zaczęły stawiać projekty mające na celu poprawę estetyki, oferty kulturalnej i poziomu życia, które stanowią element przyciągający wysoko wykwalifikowanych specjalistów, a wraz

portowych, zamykających się w obrębie pojedynczych jednostek terytorialnych oraz zapewnienie dostępu do systemów transportowych wyższego rzędu. 
Tab. 2. Aspekty transportowe i infrastrukturalne klasycznych teorii rozwoju.

\begin{tabular}{|c|c|c|}
\hline Teoria & Główni autorzy & Odniesienia infrastruktury transportu \\
\hline $\begin{array}{l}\text { Klasyczne teorie lokalizacji } \\
\text { i aglomeracji }\end{array}$ & $\begin{array}{l}\text { A. Weber, A. Lösch, A. Marshall, } \\
\text { W. Isard, E. Hoover }\end{array}$ & - punkty węzłowe jako główny czynnik lokalizacyjny \\
\hline Teorie polaryzacji & $\begin{array}{l}\text { F. Perroux, P. Pottier, S. Lasuen, } \\
\text { G. Myrdal, O. Hirschman }\end{array}$ & $\begin{array}{l}\text { - inwestycje infrastrukturalne jako element polaryzacji, } \\
\text { - kanały dyfuzji innowacji, } \\
\text { - pojęcia efektu osiowego i efektu tunelu }\end{array}$ \\
\hline $\begin{array}{l}\text { Strategie rozwoju } \\
\text { zrównoważonego } \\
\text { i niezrównoważonego }\end{array}$ & $\begin{array}{l}\text { R. Nurkse, P. Rosenstein-Rodan, } \\
\text { P. Nijkamp, O. Hirschman }\end{array}$ & $\begin{array}{l}\text { - rozwój przez infrastrukturę, } \\
\text { - „pchnięcie infrastrukturalne”, } \\
\text { - strategie akceptujące przejściowy niedostatek } \\
\text { urządzeń infrastrukturalnych }\end{array}$ \\
\hline Modele keynesowskie & J. Keynes, F. Harrod, E. Domar & $\begin{array}{l}\text { - efekty popytowe inwestycji infrastrukturalnych, } \\
\text { - konieczność interwencji państwa }\end{array}$ \\
\hline $\begin{array}{l}\text { Neoklasyczny model } \\
\text { Solowa }\end{array}$ & R. Solow & $\begin{array}{l}\text { - infrastruktura jako potencjalne źródło „wypychania” } \\
\text { kapitału prywatnego }\end{array}$ \\
\hline Nowa teoria wzrostu & D. Aschauer & - infrastruktura jako czynnik wzrostu \\
\hline
\end{tabular}

Źródło: Opracowanie własne na podstawie na podstawie Rosik, Szuster, 2008, s. 48.

z nimi międzynarodowe instytucje i przedsiębiorców (Kunzmann,1998).

Teorie takie jak rozwoju endogenicznego J. Schumpetera $(1934,1939)$, stadiów wzrostu W. Rostowa (1960), czy bazy ekonomicznej D. C. Northa (1981), przypisywały znacznie większą rolę od lokalizacji czynnikom jakościowym, takim jak wykwalifikowana siła robocza czy zdolności kooperacji. Rozwijając funkcje o charakterze światowym lub kontynentalnym zauważano wprawdzie rolę "twardych" czynników, takich jak rozwinięta infrastruktura czy dostępność do węzłów transportowych, ale nie były to już elementy wystarczające do inicjonowania czy dynamizacji rozwoju. W krajach wysokorozwiniętych uzasadnieniem wzrostu znaczenia „otoczenia” działalności gospodarczej stały się również osiągnięcia poprzednich okresów. Po tym jak w wyniku rozwoju społeczno-gospodarczego usunięte zostały podstawowe techniczne i technologiczne bariery podejmowania i prowadzenia działalności gospodarczej ich miejsce zaczęły zajmować szeroko rozumiane pozaprodukcyjne uwarunkowania wzrostu i rozwoju. W konsekwencji rozwinęły się poglądy, zgodnie z którymi infrastruktura transportowa jest czynnikiem istotnym, ale niewystarczającym jednak do rozwoju ${ }^{10}$.

Impulsem, który zaowocował powrotem do zainteresowań relacjami przestrzennymi stał się rozwój pro-

10 Jako przykłady w tym zakresie wskazywano rozbudowane programy inwestycyjne realizowane m.in. na Półwyspie Iberyjskim, które z braku potencjału i ruchu nie doprowadziły do istotnych zmian poziomu życia społecznego i gospodarczego obsługiwanych regionów. cesów globalizacji, potęgujący znaczenie przepływów i roli w światowych sieciach powiązań. Uwaga polityki regionalnej zaczęła zwracać się w stronę dostępności obszarów i roli nowoczesnej infrastruktury transportowej - takiej jak lotniska, autostrady, czy szybka kolej. Paul Krugman, opisujący zjawiska globalizacji w koncepcji New Economic Geography, wymienił transport i infrastrukturę wśród trzech kluczowych czynników istotnych w wyjaśnianiu procesów ekonomicznych rozwoju (Fujita, Krugman, 2004).

Efekt ewolucji zależności pomiędzy procesami rozwoju a infrastrukturą został opisany również w badaniach Petera J. Rimmera, który ostatnie zmiany określił mianem „rewolucji logistycznej”. Pod zaproponowanym pojęciem rozumiał on proces, który doprowadził do stworzenia nowoczesnej, gęstej, wielowarstwowej sieci transportowej z infrastrukturą jako nośnikiem intensywnych, wielokierunkowych powiązań, wykorzystujących lotnictwo, szybką kolej, autostrady i centra logistyczne. Zauważył również, że wielkie miasta zyskują dodatkowe atuty także dzięki infrastrukturze punktowej - takiej jak porty lotnicze, zintegrowane węzły przesiadkowe, terminale i parki logistyczne, które stanowią węzły transportowe, łączące regiony z gospodarką globalną (Rimmer, 2004; Rimmer, Kam, 2018).

Współczesne badania nad czynnikami rozwoju regionalnego nadal podkreślają kluczową rolę gospodarki opartej na wiedzy i umiejętności tworzenia lub adaptowania innowacji. Wskazująjednocześnie na niezbędne środowisko, ułatwiające procesy uczenia się i interakcji między aktorami rozwoju społecznogospodarczego. Regiony odnoszące sukcesy stanowią 
Tab. 3. Elementy infrastrukturalne w wybranych, współczesnych koncepcjach rozwoju regionalnego.

\begin{tabular}{|l|l|l|l|}
\hline \multicolumn{1}{|c|}{ Teorie/Koncepcje } & \multicolumn{1}{|c|}{ Instrumenty rozwoju } & \multicolumn{1}{|c|}{$\begin{array}{c}\text { Rola } \\
\text { infrastruktury } \\
\text { transportu }\end{array}$} & $\begin{array}{c}\text { Paradygmat } \\
\text { rozwoju } \\
\text { infrastruktury }\end{array}$ \\
\hline Neoklasyczne & $\begin{array}{l}\text { Wzrost mobilności czynników produkcji - } \\
\text { kapitału (zachęty dla firm) i pracowników } \\
\text { Rozwój i poprawa stanu infrastruktury } \\
\text { technicznej }\end{array}$ & bardzo duża & wyprzedzający \\
\hline Bazy ekonomicznej & $\begin{array}{l}\text { Specjalizacja w tych dziedzinach, w których } \\
\text { przewaga komparatywna jest największa } \\
\text { Wspieranie rozwoju bazy ekonomicznej }\end{array}$ & ograniczona & wtórny \\
\hline Lokalizacyjne & $\begin{array}{l}\text { Poprawa czynników lokalizacji - czynniki } \\
\text { "twarde” i,miękkie” }\end{array}$ & duża & wyprzedzający \\
\hline $\begin{array}{l}\text { Biegunów wzrostu } \\
\text { i kumulatywnej } \\
\text { przyczynowości }\end{array}$ & $\begin{array}{l}\text { Wspieranie tworzenia biegunów rozwoju } \\
\text { (w tym również w regionach peryferyjnych) }\end{array}$ & ograniczona & wtórny \\
\hline Cyklu życia produktu & $\begin{array}{l}\text { Wspieranie warunków do tworzenia } \\
\text { innowacji w regionach peryferyjnych }\end{array}$ & ograniczona & wtórny \\
\hline Centrum-peryferii & Redystrybucja władzy gospodarczej & ograniczona & wtórny \\
\hline Rozwoju endogennego & $\begin{array}{l}\text { Rozwój zasobów ludzkich } \\
\text { Tworzenie warunków do rozwoju małych } \\
\text { iśrednich przedsiębiorstw } \\
\text { Wspieranie innowacyjności }\end{array}$ & $\begin{array}{l}\text { obraniczona } \\
\text { Polaryzacja regionalna } \\
\text { Rozbieżne efekty inwestycji w infrastrukturę } \\
\text { wewnątrzregionalną i międzyregionalną }\end{array}$ & wtórny \\
\hline $\begin{array}{l}\text { Nowa geografia } \\
\text { ekonomiczna }\end{array}$ & duża & mieszany \\
\hline
\end{tabular}

Źródło: Opracowanie własne na podstawie Smętkowski (2013), s. 64.

węzły ogniskujące światowe przepływy informacji i kapitału. W tej optyce transport, jako czynnik rozwoju regionalnego bezpośrednio związany z lokalizacją, nadal odpowiada za niezbędne przepływy osób oraz towarów i przekłada się na wymiar ekonomiczny, społeczny, techniczny, technologiczny oraz ekologiczny rozwoju (Głuszczuk, 2011; Pająk i in., 2016; Churski i in., 2018).

Współczesne strategie wzrostu dotyczą procesów tworzenia wiedzy i jej dyfuzji, adaptacyjnego dostosowania lokalnych zasobów do uwarunkowań globalnych oraz wykorzystania efektów synergii i procesów uczenia się w celu osiągnięcia przewagi konkurencyjnej (Smętkowski, 2013). Zagadnienie dostępności łączy się w nich z rolą ponadregionalnego węzła, skupiającego różne rodzaje przepływów zarówno materialnych, jak i niematerialnych. Tym samym jakość i efektywność transportu przekłada się w ujęciu ekonomicznym na koszty transakcyjne całego układu terytorialnego, i jednocześnie determinuje szanse rozwojowe danego układu terytorialnego (Capello, 2007).

Polityka rozwoju powiązań transportowych z ośrodkami metropolitalnymi jest istotna również w przypadku regionów słabiej rozwiniętych, w których oczekiwany jest postęp w zakresie otoczenia instytucjonalnego rynku pracy, czy jakości życia dla wysoko wykwalifikowanych specjalistów (Wołek, Hebel, 2019).
Efektywne przepływy są szansą dla układów terytorialnych, które potrafią zaadaptować i przyswoić innowacje wytworzone w regionach rdzeniowych (Aghion, Howitt, 2005). W tym wymiarze dostępność infrastruktury transportowej wysokiej jakości staje się elementem niwelowania podziałów i instrumentem integracji regionalnej uzupełniającym zmniejszanie dystansu społecznego i instytucjonalnego.

Wymienione w tab. 3 przykłady współczesnych koncepcji rozwoju regionalnego wskazują, że mimo rozwoju gospodarki cyfrowej i coraz doskonalszych form zdalnej komunikacji nie zanikła rola infrastruktury transportu, jako czynnika rozwoju sieci osadniczej i atrakcyjności inwestycyjnej. Co charakterystyczne, współczesne koncepcje rozwoju regionalnego - nawet jeśli akcentują rolę czynników transportowych - rzadko odwołują się do paradygmatu "wyprzedzającej" roli infrastruktury. W zdecydowanej większości prac teoretycznych transport traktowany jest jako medium niezbędne, ale nie przesądzające o rozwoju. Przyjmuje się, że powinien rozwijać się harmonijnie, wraz z pozostałymi elementami otoczenia społeczno-gospodarczego, z zachowaniem skali inwestycji proporcjonalnej do potrzeb.

W rezultacie, mimo dynamicznego rozwoju alternatywnych technologii i form komunikacji, transport, zarówno wewnętrzny, jak zewnętrzny stanowi nadal 
medium niezbędne do efektywnego funkcjonowania współczesnych układów terytorialnych. Po okresie ograniczania roli tego czynnika rozwoju częściowo odzyskuje on pozycję w wyjaśnianiu procesów rozwoju społeczno-ekonomicznego i różnic pomiędzy poszczególnymi układami terytorialnymi (Krugman 1991; 1995).

Podsumowując tę część rozważań warto zauważyć, że klasyczne teorie rozwoju regionalnego kładły duży nacisk na kwestie transportowe, a inwestycje w tym zakresie uznawały za jeden z kluczowych czynników stymulujących rozwój społeczno-gospodarczy. Jednocześnie, wychodząc z założenia wolnej konkurencji nie rekomendowały one bezpośredniego udziału władz publicznych w przebiegu procesów gospodarczych, takich jak prowadzenie operacyjnej działalności transportowej.

Począwszy od połowy XX w. koncepcje rozwoju regionalnego zaczęły sięgać po narzędzia interwencjonizmu jako remedium na narastające różnice międzyregionalne. Wskazywały w tym zakresie na dalsze przyspieszenie rozwoju w regionach wysoko rozwiniętych, kontrastujące ze zjawiskami problemowymi kumulującymi się na obszarach zacofanych (Gałązka, 2017). Transport służył tu przede wszystkim jako narzędzie do tworzenia kanałów redystrybucji, a tym samym nie tylko infrastruktura, ale również kształtowanie sieci połączeń stawały się obszarem aktywności władz publicznych.

Większość koncepcji naukowych dotyczących rozwoju regionalnego, powstałych w okresie po II wojnie światowej do lat 80. XX w., uwzględniała wiodącą rolę odgórnej, "zewnętrznej” pomocy dla słabo rozwijających się regionów. Trend ten zaczęły równoważyć dopiero propozycje współczesne, zakładające interwencję "od dołu” (Gałązka, 2017). W sferze transportowej uwypuklają one nie tyle rolę infrastruktury, jako elementu powiązania regionów wysoko i nisko rozwiniętych, ale również jako elementu tworzącego wewnętrzny potencjał, który wzbogaca określoną lokalizację i tym samym podnosi jej atrakcyjność i wartość.

\section{Podsumowanie}

Dostępność warunkowana występowaniem barier naturalnych, ale też jakością stosunków gospodarczych i politycznych z otoczeniem była historycznie jednym z podstawowych czynników decydujących o szansach rozwoju danego kraju czy regionu. Początkowo miała ona wymiar przede wszystkim fizyczny. Wraz ze wzrostem roli kapitału publicznego, przyjmującego również formę infrastruktury transportowej, w coraz większym stopniu uzależniała się od odpowiedniego procesu przygotowania, planowania i rea- lizacji inwestycji, a tym samym zainteresowania władz publicznych.

Wybrane i opisane przykłady z bardzo bogatej literatury przedmiotu wskazują, że znaczenie czynnika przestrzennego, a następnie infrastrukturalno-transportowego w teoriach rozwoju stopniowo modyfikowało czynnik lokalizacji. Transport we współczesnych koncepcjach w zdecydowanie mniejszym stopniu decyduje o atrakcyjności czy konkurencyjności układów terytorialnych, ale w wielu przypadkach nadal pozostaje źródłem przewag związanych z dostępem do czynników produkcji, jak również korzyści płynących z usprawniania i integracji procesów produkcyjnych.

Nawet jeśli przyjmie się optykę, zgodnie z którą rozwój społeczno-gospodarczy jest determinowany przede wszystkim specyfiką danego miejsca, czy też opiera się na relacjach i przepływach niematerialnych, to jednak sprawne funkcjonowanie stworzonych na tej bazie sieci i powiązań wymaga zaangażowania odpowiedniej infrastruktury. Co więcej, rozbudowane komponenty infrastrukturalne programów rozbudowy, aktywizacji społeczno-gospodarczej, a ostatnio również odbudowy gospodarki po kryzysie wywołanym doświadczeniem światowej pandemii wskazują, że oczekiwania wobec efektów inwestycji infrastrukturalnych nie słabną.

W świetle powyższych rozważań uzasadniona wydaje się być konkluzja, zgodnie z którą kształt, funkcjonalność i jakość systemów transportowych jako uniwersalnego komponentu wszystkich procesów gospodarczych i przejawów życia społecznego - jeszcze przez długi czas będzie wpływała na atrakcyjność regionów, zarówno jako miejsca zamieszkania, jak i inwestowania. Tym samym w odpowiedzi na postawione we wstępie pytanie badawcze można stwierdzić, że współczesne teorie rozwoju regionalnego postrzegają infrastrukturę zarówno jako element zapewniający dostępność zewnętrzną, jak i równolegle część wewnętrznego potencjału, który wzbogaca opisywaną lokalizację, podnosząc jej atrakcyjność i wartość. Stąd jakość i funkcjonalność infrastruktury w wymiarze średnio i długodystansowym jest istotna z punktu widzenia relacji z otoczeniem, natomiast w wymiarze lokalnym i punktowym ma kluczowe znaczenie dla mieszkańców i zlokalizowanych tu podmiotów oraz instytucji.

\section{Piśmiennictwo}

Aghion P., Howitt P., 2005, Appropriate Growth Policy: A Unifiying Framework, Journal of the European Economic Association, 4(2-3), 269-314.

Bąk M., 2014, Infrastruktura transportu w rankingach konkurencyjności - kraje Europy Środkowej i Wschodniej 
na tle wiodących gospodarek, Ekonomika Transportu i Logistyka, 49, 107-121.

Banister D., 2007, Sustainable Transport: Challenges and Opportunities, Transportmetrica, 3, 91-106.

Barca F., McCann P., Rodríguez-Pose A., 2012, The case for regional development intervention: place-based versus place-neutral approaches, Journal of Regional Science, 52, 134-152.

Brdulak J., Pawlak P., Krysiuk C., Zakrzewski B., 2014, Podstawowe teorie lokalizacji działalności gospodarczej oraz znaczenie czynnika transportu, Logistyka, 6, 2254-2260.

Burnewicz J., 2014, Infrastruktura transportu jako czynnik rozwoju ekonomicznego, Ekonomika Transportu i Logistyka, 49, 7-54.

Burnewicz J., Wojewódzka-Król K., 1993, Europejska polityka transportowa, Wydawnictwo Uniwersytetu Gdańskiego, Gdańsk.

Capello R., 2007, Regional Economics, Routledge, London.

Churski P., Perdał R., Konecka-Szydłowska B., Herodowicz T., 2018, Redefinicja czynników rozwoju regionalnego w świetle megatrendów społeczno-gospodarczych, Studia Regionalne i Lokalne, 3(73), 70-98.

Cigu E., Agheorghiesei D., Gavriluță A., Toader E., 2019, Transport Infrastructure Development, Public Performance and Long-Run Economic Growth: A Case Study for the Eu-28 Countries, Sustainability, 11(1).

Domański B., 1992, Percepcja i waloryzacja środowiska naturalnego iantropogenicznego, Wydawnictwo Uniwersytetu Warszawskiego, Warszawa.

Frey R., 1970, Infrastruktur. Grundlagen der Planung Öffentlicher Investitionen, J.C.P. Mohr, Tübingen.

Fujita M., Krugman P., 2004, The new economic geography: Past, present and the future, Papers in Regional Science, 83, 139-164.

Gałązka A., 2017, Teoretyczne podstawy rozwoju regionalnego - wybrane teorie, czynniki i bariery rozwoju regionalnego, Studia BAS, 1(49), 9-61.

Głuszczuk D., 2011, Istota rozwoju regionalnego i jego determinanty, Ekonomia, 5(17), 68-80.

Gorzelak G., Smętkowski M., 2005, Rozwój metropolii w gospodarce informacyjnej: znaczenie układu globalnego i regionalnego, Studia Regionalne i Lokalne, 2 (20), 5-23.

Grzywacz W., Wojewódzka-Król K., Rydzkowski W., 2005, Polityka transportowa, Wydawnictwo Uniwersytetu Gdańskiego, Gdańsk.

Hausner J., 2008, Zarządzanie publiczne, Scholar, Warszawa. Hoszman A., 2014, Dostępność transportowa: determinanty, pomiar i fekty społeczno-gospodarcze, SGH, Warszawa.

Hryniewicz J., 2017, Czynniki lokalnego rozwoju gospodarczego - 20 lat później, Samorząd Terytorialny, 6, 5-23.

Impact of Transport Infrastructure Investment on Regional Development, 2002, OECD, Paryż.

Jaskólski M., 1999, Słownik historii doktryn politycznych, Wydawnictwo Sejmowe, Warszawa.

Kamińska T., Rusak M., 2000, Kryteria społeczno-ekonomicz- ne decyzji infrastrukturalnych w transporcie, Przegląd Komunikacyjny, 3, 12-17.

Knieper K., 1966, Wettbewerbsverzerrungen in der Verkehrswirtschaft bei finanzieller Eigenständigkeit der Infrastruktur, Vandenhoeck \& Ruprecht, Göttingen.

Komornicki T., 2010, Ocena wpływu inwestycji infrastruktury transportowej realizowanych w ramach polityki spójności na wzrost konkurencyjności regionów, Ministerstwo Rozwoju Regionalnego, Warszawa.

Koźlak A., 2014, Miejsce dostępności transportowej w koncepcji czynników konkurencyjności regionów, Ekonomika Transportu i Logistyka, 49, 75-89.

Krugman P., 1991, Increasing returns and economic geography, Journal of Political Economy, 99(3), 483-499.

Krugman P., 1995, Development Geography, and Economic Theory, MIT Press, London.

Krzemiński S., 2005, Źródła finansowania rozwoju transportu, Przegląd Komunikacyjny, 12, 14-16.

Kunzmann K., 1998, Planning for spatial equity in Europe, International Planning Studies, 3(1), 101-120.

Lakshmanan T., 2011, The broader economic consequences of transport infrastructure investments, Journal of Transport Geography, 19(1), 1-12.

Liberadzki B., Mindur L., 2007, Polityka transportowa państwa - podstawowe założenia [w:] B. Liberadzki, L. Łatuszyńska M., 2004, Metody przewidywania efektów rozwoju międzynarodowej infrastruktury transportu, Problemy Ekonomiki Transportu, 1, 29-39.

Majewski J., 2016, Analiza doktryn współczesnej polityki transportowej, Ekonomika Transportu i Logistyka, 59, 77-87.

Markowski K., 1992, Rola państwa w gospodarce rynkowej, PWE, Warszawa.

Matczak R., Churski P., Komornicki T., Mogiła Z., Szlachta J., Zaleski J., Zaucha J., Żuber P., 2020, Przestrzenny wymiar polityki spójności Unii Europejskiej w Polsce w latach 20212027, Policy Brief KPZK PAN, 2020/1.

Meersman H., Nazemzadeh M., 2017, The contribution of transport infrastructure to economic activity: The case of Belgium, Case Studies on Transport Policy, 5(2), 316-324.

Mindur L. (red.), 2007, Uwarunkowania rozwoju systemu transportowego Polski, Instytut Technologii Eksploatacji, Radom.

Nieciuński W., 1991, Rozpad i dziedzictwo socjalizmu realnego a transformacja społeczeństwa, Wydawnictwo Uniwersytetu Warszawskiego w Białymstoku, Białystok. North D., 1981, Structure and Change in Economic History, W. W. Norton, New York.

Pająk K., Dahlke P., Kvilinskyi O., 2016, Determinanty rozwoju regionalnego - współczesne odniesienie, Roczniki Ekonomiczne Kujawsko-Pomorskiej Szkoły Wyższej w Bydgoszczy, 9, 109-122.

Paprocki W., Pieriegud J., 2005, Wpływ procesów demonopolizacji i konsolidacji w transporcie na sprawność i efektywność jego funkcjonowania, SGH, Warszawa. 
Pastuszka S., 2014, Interwencjonizm czy liberalizacja w polityce regionalnej?, Gospodarka Narodowa, 6(274), 5-29.

Pawłowska B., 2014, Polityka transportowa w zakresie inwestycji infrastrukturalnych w realizacji inicjatyw strategii Europa, Ekonomika Transportu i Logistyka, 49, 55-74.

Ratajczak M., 2000, Infrastruktura a wzrost i rozwój gospodarczy, Ruch Prawniczy, Ekonomiczny i Socjologiczny, 4, 83-102.

Rietveld P., Stough R., 2004, Institutions, regulations and sustainable transport: a cross-national perspective, Transport Reviews, 24(6), 707-719.

Rimmer P., 2004, Global flows, local hubs, platforms, corridors and regional economic integration in Northeast Asia, Journal of International Logistics and Trade, 1(2), 1-24.

Rimmer P., Kam B., 2018, Consumer Logistics: Surfing the Digital Wave, Edward Elgar Publications, Cheltenham.

Rodriguez-Pose A., Fratesi U., 2004, Between development and social policies: the impact of European Structural Funds in Objective 1 regions, Regional Studies, 38(1), 97-113.

Rosik P., 2004, Infrastruktura transportu jako czynnik rozwoju regionalnego, Zeszyty Studiów Doktoranckich, 19, 45-66.

Rosik P., Szuster M., 2008, Rozbudowa infrastruktury transportowej a gospodarka regionów, Wydawnictwo Politechniki Poznańskiej, Poznań.

Rydzkowski W., Wojewódzka-Król K., 1997, Współczesne problemy polityki transportowej, PWE, Warszawa.

Schumpeter J., 1934, Theory of Economic Development, Transaction Books, New Brunswick, New Jersey.

Schumpeter J., 1939, Business Cycles. A theoretical, Historical and Statistical Analysis of the Capitalist Process, McGraw-Hill Book Company, New York.

Schumpeter J., 1952, Process of Economic Growth, W. W. Norton, New York.
Ślawska J., 2019, Czynniki wyboru modelu świadczenia usługi lokalnego transportu w Polsce, Studia Regionalne i Lokalne, 4(78), 95-114.

Smętkowski M., 2013, Rozwój regionów i polityka regionalna w krajach Europy Środkowo-Wschodniej w okresie transformacji i globalizacji, Wydawnictwo Naukowe Scholar, Warszawa.

Smętkowski M., Gorzelak G., Kozak M., Olechnicka A., Płoszaj A., Wojnar K., 2012, Europejskie metropolie i ich regiony: Od krajobrazu gospodarczego do sieci metropolii, Wydawnictwo Naukowe Scholar, Warszawa.

van Wee B., 2016, Accessible accessibility research challenges, Journal of Transport Geography, 51, 9-16.

Ważna A., 2014, Relacje między inwestycjami infrastrukturalnymi w transporcie a innymi czynnikami determinującymi poziom konkurencyjności regionu, Ekonomika Transportu i Logistyka, 49, 91-106.

Wielowiejski J., 1984, Na drogach i szlakach Rzymian, PIW, Warszawa.

Wittneben B., Bongardt D., Dalkmann H., Sterk W., Baatz C., 2009, Integrating Sustainable Transport Measures into the Clean Development Mechanism, Transport Reviews, 29, 91-113.

Wojewódzka A., 2000, Infrastruktura jako czynnik rozwoju lokalnego i regionalnego, Logistyka, 3.

Wojtowicz D., Olechnicka A., 2016, Short-Term Problems and Long-Term Oriented Policy: EU Cohesion Policy Responding to Crisis, Barometr Regionalny, 14(3), 25-32.

Wołek M., Hebel K., 2019, The quality of life in sustainable urban mobility planning. The case study of the Polish city of Piotrków Trybunalski, Prace Naukowe Uniwersytetu Ekonomicznego, 63(10), 129-143. 